\title{
Financial instruments of "green" economy development in Russia
}

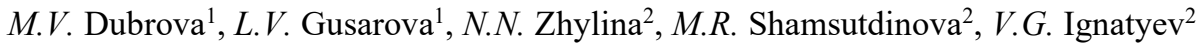 \\ ${ }^{1}$ Financial University under the Government of the Russian Federation \\ ${ }^{2}$ Kazan Cooperative Institute, Branch of Russian University of Cooperation
}

\begin{abstract}
Environmental problems are getting worse every year. The root cause of green finance is the climate change, pollution and the depletion of natural capital that threaten Russia's competitiveness and productivity. Green financing means providing finance while enhancing the resource efficiency and reducing the impact on the environment and the global climate. Balanced adherence to financial, economic and environmental criteria is the main foundation. The new emerging financial instruments of a green economy do not have technical fundamental differences, but qualitatively form new conditions for the responsible investment process. The Russian green finance market emerged in 2018. The past period can be characterized by both a quantitative and a qualitative breakthrough in the system of green finance in Russia. At the same time, the issues of developing a mechanism of state support for the activities of non-profit organizations in the field of green finance, the participation of non-profit organizations in the implementation of environmental projects through the development of green financing instruments require consideration.
\end{abstract}

\section{Introduction}

Green financing means providing finance while enhancing the resource efficiency and reducing the impact on the environment and the global climate. Green finance instruments include the green loans and the green bonds. Green banks and green funds are engaged in green financing.

In practice, the "green" bonds are the bonds of issuers engaged in the field of alternative energy, environmentally friendly modes of transport, creation of smart buildings and others aimed at projects on ecology and sustainable development. Today, almost 50 countries around the world use similar types of financing.

For securities to be recognized as "green", which means the possibility to entertain the public support and a number of preferences, they should pass certification for compliance with certain criteria, which is carried out by consulting, engineering, legal and auditing companies, as well as rating agencies.

Such bonds are circulated on special stock exchanges at reduced rates. They are of particular interest to large financial institutions. Very often, governments and central banks subsidize the interest rate on green projects. Pension funds are most willing to invest in such bonds. 


\section{Materials and methods}

The research utilized the general scientific research methods, e.g. comparison, analysis and synthesis, grouping, comparison, graphical method of analysis, trend and statistical analysis. The logical, historical and complex approaches to the study of theoretical materials were used as well.

The research methodology includes the examination, generalization, assessment of the accumulated knowledge and experience of domestic and foreign scientists.

A critical review of regulations governing the issuance and circulation of financial instruments made it possible to identify problems in the development of a "green" economy, to identify the need to clarify and legislatively consolidate key concepts, features of the issuance and circulation of "green" bonds, to develop directions of state support for the development of the "green" market financial instruments.

\section{Results and discussion}

Russia faces the problem of the lack of a large number of participants in the largest organizations in the field of responsible investment, which does not allow it to contribute to the development of solutions to global problems. This problem should be solved by joint efforts of both the government and market participants.

The dynamics of environmental investments in the Russian Federation over the past decade (Fig. 1) allows us to conclude that the market for responsible investment is developing, the "green economy" is becoming a vector of innovative projects.

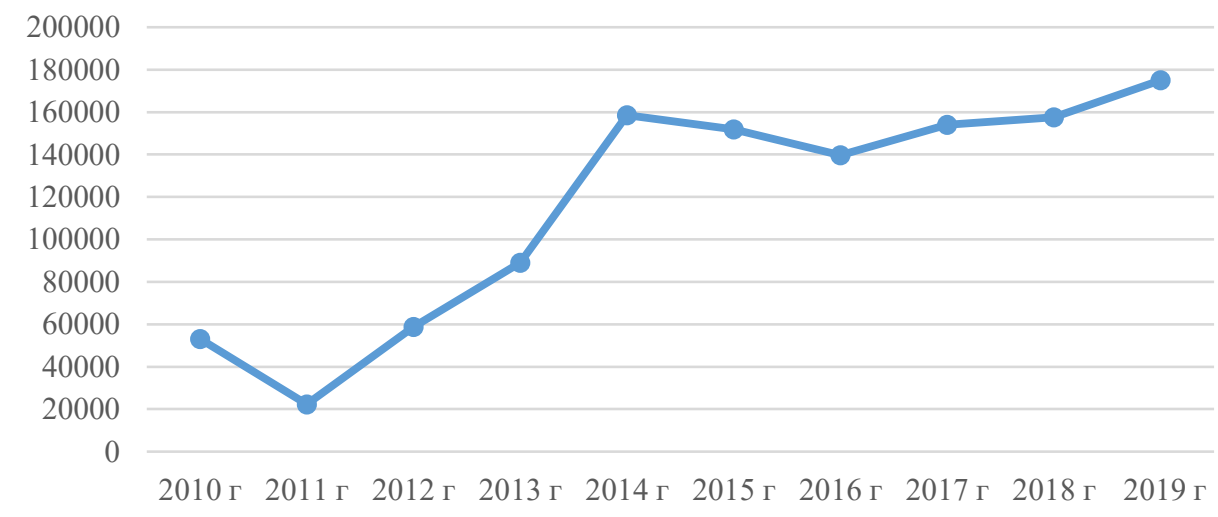

Fig. 1. The fixed assets investments aimed at environmental protection and rational use of natural resources, RUR mln

The dynamics of investments in fixed assets aimed at environmental protection and rational use of natural resources allows us to conclude that a system of financing environmental projects has been formed, which reinforces the previously stated thesis about the development of a "green economy" and "green finance" in Russia.

The first full-fledged support platform for environmental projects "Sustainable Development Sector" in the Russian financial market is an example of the green finance idea implementation. At the beginning of 2020, five issuers in Russia have placed seven issues of green bonds for a total of 7.55 RUR bln and 500 EUR mln.

Currently, a new ecological culture of life is being formed all over the world, while green projects are developing, which, in addition to environmental friendliness, include universal approaches and acquire an ideological sound. Russia sees an increase in financing in the field of the green economy and investment practice in green projects, which indicates the inclusion 
of a global ecosystem in the global ecological framework. National projects in Russia correlate with the UN Sustainable Development Goals, are complex in nature, balanced by three sustainable development components and compliant with the economic, social and environmental factors of the country's development. Trends in green finance in Russia are important for changes in the eco-financial sphere and the global financial market. The Russian economy is close to the ten largest world economies, while the Russian financial market is not even included in the first hundred of financial markets. Pursuant to the World Competitiveness Index, the Russian financial market is lower than the Turkmen one. Therefore, the development of the eco-financial sector will make it possible to remedy the actual situation and allow to attract additional financial resources, which are less expensive than in Russia, for the Russian green projects.

Financial resources are needed to save the environment, and it is important to optimize the cost of attracting them. In addition, the investors should be shown the benefits of investing in green projects, which can be, for example, image-building. In this regard, there is a tendency to attract institutional investors who, owing to green investments, could improve their image.

It is beneficial for Russia to use green finance, since ignoring the environmental problems associated with economic growth jeopardizes the results already attained. Such lack of action may cause significant economic, social and environmental consequences for the country. This damages not only the Russian economy, but also the health of citizens. The long-term functioning of "green finance" is also associated with many unresolved economic problems.

Two roles are distinguished in the green project relations framework: institutions and organizations of the public and private sectors. They stimulate the development of a green financial market and promote efficient investment and resource efficiency. In the private sector, banks play a leading role in attracting institutional investors.

One of the priority tasks of enhancing innovative financing in Russia is the formation and development of a market for "green" financial instruments, which includes bond loans, loans and other instruments for financing the environmental projects. The list of these instruments is described in the Action Plan of the Ministry of Economic Development of the Russian Federation for the period from 2019 to 2024, pursuant to which national rules and standards for the verification of green financial instruments are being actively developed, contributing to the development of the green bond market, and, consequently, the development of a green economy. It is necessary to increase the rate of promotion of "green" financial instruments to ensure the formation of a competitive national financial market in Russia. The lag in the development of the market for "green" financial instruments may impact the implementation of environmental projects, since investment processes associated with sustainable development projects require a transparent financial mechanism. Consequently, the development of the market for green financial instruments in Russia requires the formation of a regulatory framework that facilitates the verification of these instruments and their involvement in the investment process.

The legal consolidation of the status of "green" bonds, the consolidation of the issue procedure and the features of the issue, the requirements for information disclosure will contribute to the verification of such financial instruments and the accelerated development of the green bond market.

According to experts, the Russian green bond market capacity exceeds 1 trln RUB, therefore, at the moment the potential of this instrument is underestimated, which means it is highly attractive for both issuers and investors. Currently, the official "green" bond status is assigned to the limited list of financial instruments enshrined in the relevant register, including the "Resource Saving of the Khanty-Mansi Autonomous Okrug" bonds (construction and operation of a landfill for placement, neutralization and processing of solid municipal waste); Bank Centrinvest (energy efficient projects, renewable energy sources and 
environmentally friendly transport); JSC Commercial Real Estate FPK Garantinvest (modernization of shopping and multifunctional centers and the green technology implementation), JSC Russian Railways, which issued the green Eurobonds aimed at foreign investors (financing and refinancing the purchase of passenger electric trains). The list of green bonds is not limited to the listed issuers, but many issues do not have the official status of green instruments, despite financing projects related to environmental protection.

The noticeable event in the development of the market of "green" financial instruments in Russia was the accession of Moscow Exchange to the "Sustainable Stock Exchanges" (SSE) global initiative in April 2019. Joining the SSE and cooperation with the Russian Union of Industrialists and Entrepreneurs (RUIE) - "Responsibility and Openness" resulted in the daily calculation of two sustainable development indices. The first index is calculated on the basis of the prices of shares of 22 issuers that are leaders in information disclosure in the field of ESG, and the second index - "Sustainable Development Vector", is calculated on the basis of the prices of shares of 15 issuers that showed the best dynamics of indicators in the field of sustainability and corporate social responsibility.

The growth of the green bond market is impossible without the implementation of a mechanism of state support and a system of additional benefits for market participants, both for issuers and for investors.

The green bond market state support mechanism may include the following measures:

1) Legislating the green bond principles and standards. The participation of the state in unification of green financial instruments makes it possible to ensure market transparency, proving the reliability of the instrument and monitoring the implementation of environmental projects for the financing of which investments are formed.

2) Regulation of liquidity and activity of the financial market through the issuance of "green" bonds by the state (issuance of bonds by development institutions, subjects and municipalities to maintain the priority and strategic investment projects for sustainable development).

3) Ensuring risk management by scaling green projects, issuing collateralized green bonds, providing institutional investors with access to the bond market; securitization of loans at the design development stage.

4) Determination of the financial incentive (incentives for environmental taxes and fees, government guarantees, budget subsidies, direct government funding at the stage of preparation, project design, government insurance, etc.) provision conditions.

5) Provision of guaranteed demand for financial instruments through public procurement with a priority of environmental components.

It seems necessary to develop and deploy the mechanisms for the creation and development of a green cluster in the economy on the basis of public-private partnership, which will allow in the long term to obtain the effect of a double benefit - financial "recovery" of the economy and environmental benefits.

A new stage in the development of the modern world financial system is the globalization of "green" finance, which is an objective process and coincides in time with global reforms. The peculiarity of the analyzed process is the formation of a global market for "green" financial instruments, the innovative nature of the initiatives and national practices of countries with developing markets.

\section{Conclusion}

The recommended measures for the development of the entire sphere of the "green economy" in Russia were presented, but they are primarily aimed at supporting the non-profit organizations' private initiatives, which are primarily interested in the fact that their activities became known not only in local level, but also at the level of the constituent entity of the 
Russian Federation and the federal level. Without the proper level of financial support from the state and private investment, non-profit organizations are doomed to develop ineffective and inefficient innovative projects.

Undoubtedly, nobody canceled the innovative environmental project grant support mechanism. However, as the foreign countries' promising experience shows, the "green economy" has much more financial resources and instruments than a conventional economy. The creation of only a green investment bank, by analogy with Great Britain, will allow a significant amount of financial resources to be directed to solving the most pressing and complex environmental problems.

\section{References}

1. V.V. Arkhipova, HSE Economic Journal, 21(2), 312 (2017)

2. Activity of NPO within year of ecology of 2017, https://mediarepost.ru/

3. M. L. Dorofeyev, Banking, 4, 23 (2020)

4. T.M. Kozhevnikova, S.G. Ter-Akopov, Social and economic phenomena and processes, 3 (049), 78 (2013)

5. A.V. Kucherov, O.V. Shibileva, Young scientist, 4, 561 (2014)

6. K.G. Musailova, World trend in "green" economy and prospect of "green" finance in Russia, 39 (2018)

7. Center of Competence and Green Expertise of the National Association of Concessionaires and Long-Term Investors in Infrastructure. Annual report "Green Finance in Russia 2020" (2020)

8. V.A. Tsvetkov, A.G. Gurinovich, V.A. Vernikov, I.Yu. Fedorova, M.V. Dubrova, A.Z. Namitulina, Abashilov Shekhmagomedovich Khadzhi-Murad, International Journal Of Engineering And Technology, 10(2), 1258 (2019)

9. ESG factors in investment. - MIRBIS, (2019), https://www.pwc.ru/ 